\title{
KEEFEKTIFAN PENGGUNAAN MODEL PEMBELAJARAN KOOPERATIF TIPE GRUP INVESTIGASI DAN STAD PADA MATERI PERKEMBANGAN TEKNOLOGI DI SEKOLAH DASAR
}

\author{
Herniwati Wahid \\ Program Studi PGSD Fakultas Keguruan dan Ilmu Pendidikan Universitas Cokroaminoto Palopo \\ herniwati.wahid@yahoo.com
}

\begin{abstract}
ABSTRAK
Model-model pembelajaran tidak semua sudah diterapkan di kelas. Seorang guru harus mampu memilih model pembelajaran yang tepat dan memperhatikan keadaan atau kondisi siswa. Banyak model kooperatif yang dapat digunakan dalam pembelajaran IPS tetapi harus dicari model yang efektif. Masalah dalam penelitian ini adalah, bagaimanakah hasil proses pembelajaran IPS siswa, bagaimanakah hasil analisis deskriptif model, dan bagaimana keefektifan model pembelajaran kooperatif tipe Grup Investigasi dibandingkan tipe STAD mata pelajaran IPS materi perkembangan teknologi yang diterapkan pada siswa sekolah SSN dan RSSN?. Pendekatan yang digunakan dalam penelitian ini adalah kuantitatif dengan metode eksperimen dan memberikan opic diskriptif untuk mengetahui gambaran selama proses pembelajaran menggunakan cara Randomized Control Group Design. Pengambilan sampel menggunakan teknik Purposive random sampling menggunakan 2 kelas eksperimen dan 2 kelas opic diambil dari 91 SD sebagai sampel yang ada di Kota Parepare. Intrumen penelitian, lembar observasi afektif dan psikomotorik, angket respons dan tes hasil pre-test dan post-test kognitif. Analisis data secara deskriptif, Uji keektifan dan Uji perbedaan menggunakan Uji- $t$ anava dua jalan. Hasil penelitian ini menunjukkan bahwa melalui pembelajaran.hasil penelitian pada pelaksanaan pembelajaran di sekolah SSN dan RSSN, Siswa berinteraksi opic kelompok dalam bentuk diskusi yang pada akhirnya menghasilkan suatu kesimpulan. Siswa melakukan investigasi terhadap suatu opic secara sistematis dan analitik. Hal ini mempunyai implikasi yang positif terhadap pengembangan keterampilan penemuan dan membentu mencapai tujuan.
\end{abstract}

Kata Kunci: Pembelajaran kooperatif, Model group investigation, Hasil belajar siswa.

\section{ABSTRACT}

Some of learning models are not applied yet in the class. A teacher has to able to choose the precise learning model by considering students' situation. Many of cooperative model can be applied in social learning but we have to find the effective one. The problems in this reseacrh are how are the students' process and result in social learning? How is the result of descriptive model analysis? and how is the effectiveness of cooperative learning model in group type investigation compraed with STAD in social subject by technology improvement material that is applied in class SSN and RSSN?. This research used quantitative approach by using experiment method and giving descriptive unsure to know the description during learning process using Randomized Control Group Design. Sampling technique used in this research is Purposive random sampling by using two experiment and two control classes taken from 91 elementary schools in Pare-pare. The research instrument consist of: affective and psychomotoric observations sheet, questionnaire and the result of pre test and post test cognitive test. Data analysis descriptively. Effectivity test using t-anava two tailed. The result of the research showed that by using cooperative learning with GI model SSN and RSSN, students interact in group discussion and find the conclusion of the topic discussed. Students investigate a topic systematically and analytically. It has positive implication to the skill improvement, finding and goal achieving.

Key words; cooperative learning, investigation group model, students score 


\section{PENDAHULUAN}

Pendidikan bukanlah sekadar transfer pengetahuan tapi sebagai wahana pembentukan kepribadian mulia dari pola pikir, kewajiban dan pola tingkah laku. Hal ini dapat dikaitkan dengan esensi pendidikan yaitu memperhalus budipekerti, peningkatan rasa kemanusiaan, kepedulian sosial, penumbuhan apresiasi budaya, penyaluran gagasan, penumbuhan imajinasi, serta peningkat ekspresi yang kreatif. Pendidikan adalah usaha sadar dan terencana untuk mewujudkan suasana belajar dan proses pembelajaran agar siswa secara aktif mengembangkan potensi dirinya untuk memiliki kekuatan spiritual keagamaan, pengendalian diri, kepribadian, kecerdasan, akhlak mulia, serta keterampilan yang diperlukan dirinya, masyarakat, bangsa dan negara (UU No. 20 Tahun 2003).

Diketehui pula konteks pembaharuan pendidikan, perlu dilakukan pembenahan yang difokuskan pada tiga komponen, yaitu: (1) pembaharuan kurikulum; (2) peningkatan kualitas pembelajaran; dan (3) efektivitas metode pembelajaran. Kurikulum pendidikan harus komprehensif dan responsif terhadap dinamika sosial, relevan, dan mampu mengakomodasi keberagaman keperluan, dan kemajuan teknologi. Kualitas pembelajaran harus di-tingkatkan untuk meningkatkan kualitas hasil pendidikan. Pada tataran mikro, harus ditemukan strategi atau pendekatan pembelajaran yang efektif agar lebih mampu memberdayakan potensi siswa. Kegiatan belajar-mengajar bagi peserta didik yang memiliki kemampuan dan kecerdasan luar biasa perlu dirancang dan diatur sedemikian rupa sehingga dapat dicapai hasil percepatan belajar secara optimal, dan sebaliknya. Seperti dikemukakan Arends (2013:12) bahwa banyak peserta didik yang memiliki bakat, minat, kemampuan dan kecerdasan luar biasa, bahkan sebaliknya maka dalam mengelola kegiatan belajar-mengajar dapat diterapkan pelayanan individual dan pelayanan kelompok.

Model pembelajaran yang sesuai untuk mencapai dimensi di atas, adalah model pembelajaran yang terfokus pada siswa. Trianto (2012:21) menjelaskan kegitan pembelajaran harus menekankan pada perkembangan kemampuan intelektual tinggi, memiliki kepekaan (sensitif) terhadap kemajuan belajar dari tingkat konseptual rendah ke tingkat intelektual tinggi. Sebagian guru sudah tidak asing dengan jenis-jenis model pembelajaran. Namun, model-model pembelajaran itu tidak semua sudah diterapkan di kelas. Seorang guru harus mampu memilih model pembelajaran yang tepat bagi siswa. Guru harus memperhatikan keadaan atau kondisi siswa dalam memilih model pembelajaran. Banyak model kooperatif yang dapat digunakan dalam pembelajaran IPS tetapi harus dicari model yang efektif. Trianto (2012:57) mejelaskan guru harus lebih cermat menentukan model pembelajaran kooperatif, ada lima kriteria dalam pembelajaran kooperatif yang harus diperhatikan:(1)adanya saling ketergantungan positif;(2)tanggung jawab individu; (3) interaksi tatap muka; dan (4) penampilan keterampilan kolaboratif; dan adanya proses kelompok. Salah satu model yang sering digunakan di SD adalah kooperatif tipe STAD, pembelajaran ini terdiri lima komponen utama, yaitu:(1) penyajian kelas; (2) belajar kelompok melibatkan siswa pandai;(3)sedang dan rendah disatukan;(4) kuis: dan(5) skor pengembangan dan penghargaan kelompok (Jauhar, 2011:59).Peran guru masih mendominasi aktivitas pembelajaran. Siswa kurang aktif memberikan umpan balik dan kurang memberikan pertanyaan-pertanyaan untuk menggali ide-ide yang sudah terkonstruk dalam pikiran siswa. Keberhasilan belajar siswa hanya dilihat pada hasil akhir tanpa memperhatikan proses pembelajaran sehingga hasil tes belajar siswa di kelas sangat kurang. Menurut Lenore dan Henderson (2006) menyatakan guru harus mengurangi pembelajaran yang berpusat pada guru dan memberikan lebih banyak waktu kepada siswa untuk memfokuskan pembelajaran pada aktivitas yang melibatkan interaksi antara siswa, guru dan siswa lain dalam pembelajaran kooperatif.

Hasil penerapan model pembelajaran STAD baik disekolah jenis SSN maupun RSSN menunjukkan, siswa masih mengalami kesulitan dalam menyelesaikan tugas kelompok yang diberikan guru. Pemberian tugas pada setiap kelompok mendapatkan topik yang sama dalam bentuk LKS. Siswa tidak diberikan kebebasan untuk memilih topik yang mereka senangi, sebaiknya dalam satu anggota kelompok ditugaskan untuk menyelesaikan bagian yang berlainan. Model pembelajaran tipe STAD adalah model yang sangat sederhana, dibandingkan dengan pembelajaran konvensional perbedaannya hanya terletak pada pemberian kuis dan penekanan penghargaan kelompok. STAD menggunakan sistem skor yang lebih menekankan pencapaian kemajuan daripada sekadar persentase jawaban yang benar. Nilai skor 
peningkatan individu disumbangkan ke kelompok agar mendapatkan skor tinggi (Slavin, 2010:143). Kontribusi dari siswa yang berprestasi rendah menjadi kurang, siswa berprestasi tinggi akan mengalami kekecewaan karena peran anggota yang pandai lebih dominan. Guru dituntut unutk mampu melakakuan inovasi pembelajaran yang efektif, agar tercipta suasana kelas yang menyenangkan.

Inovasi terutama ditujukan pada perubahan model pembelajaran, yaitu agar siswa senang belajar dan siswa mempelajari sesuatu kompetensi yang bermakana bagi dirinya saat ini dan perkembangannya di masa datang (meaningful learning). Sekolah SSN dan RSSN perlu mempelajari berbagai inovasi yang telah dilakukan oleh sekolah inovatif dan kemudian merancang inovasi pembelajaran yang diyakini sesuai dengan karakteristik siswanya maupun lingkungan sekolah. Warsono dan Hariyanto (2012:184) menjelaskan model pembelajaran GI melibatkan siswa secara langsung mulai awal hingga akhir pembelajaran dimana siswa dapat berkerjasama dan bertukar informasi yang ditemukan. Selanjutnya, mengevaluasi pengetahuan siswa mengenai seluruh bagian materi, maka setiap anggota merasa bertanggung jawab untuk menyelesaikan tugasnya agar berhasil mencapai tujuan dengan baik. Setiap siswa mempunyai kesempatan dan kebebasan yang sama untuk sukses. Aktivitas belajar berpusat pada siswa dalam bentuk diskusi, mengerjakan tugas bersama, saling membantu mencari informasi dan saling mendukung dalam memecahkan masalah. Keterlibatan siswa secara aktif dapat terlihat mulai dari tahap pertama sampai tahap akhir pembelajaran. Harapan dalam proses ini dapat membantu melahirkan manusia-manusia yang berbakat dan berkemampuan untuk menemukan kepribadian, konsep diri serta memiliki kecerdasan, mampu berinovasi dan berkreasi. Melalui model pembelajaran GI mata pelajaran IPS, prinsip penyelenggaraan pendidikan memberi keteladanan, membangun kemauan, dan mengembangkan kreativitas peserta didik dalam proses pembelajaran. Ahmadi dan Sofan (2011:8) menjelaskan IPS sebagai pelajaran yang merupakan fusi atau paduan sejumlah mata pelajaran sosial. Lenore dan Henderson (2006) menjelaskan perlunya menilai keefektifan berbasis kooperatif seperti kelompok invest igasi., melibatkan perubahan yang nyata dalam seluruh pendekatan dengan instruksi.
Pembelajaran GI berlaku dalam masyarakat belajar dimana siswa menentukan topik atau materi yang mereka senangi dan mencari informasi yang diketahui, ini sebagai media pembelajaran, dirancang untuk membantu terjadinya pembagian tanggung jawab ketika siswa mengikuti pembelajaran dan berorientasi menuju pembentukan manusia sosial terutama mengenai cara anggota masyarakat melakukan mekanisme sosial melalui serangkaian kesepakatan sosial. Para siswa memilih topik yang ingin dipelajari, mengikuti investigasi mendalam terhadap berbagai subtopik yang telah dipilih, kemudian menyiapkan dan menyajikan laporan secara keseluruhan (Rusman, 2010:222). Siswa yang mempelajari IPS dapat menghayati masa sekarang dengan dibekali pengetahuan tentang masa lampau umat manusia seiring dengan perkembangan teknologi, menurut Gunawan (2011:17) dimasa akan datang siswa akan menghadapi tantangan berat karena kehidupan masyarakat global selalu mengalami perubahan setiap saat. hal ini dipertegas oleh pendapat Frederiksen dalam Deena Goran dan Braude (2007:80-84) yang menyatakan bahwa pengembangan keterampilan siswa secara tidak langsung dapat mendorong pengembangan pengenalan pola dan kreativitas, yang merupakan keterampilan berharga bagi siswa dalam setiap disiplin ilmu di tingkat manapun. Model pembelajaran kooperatif terbagi atas beberapa langkah-langkah;(1) mengidentifikasi topik dan membagi siswa ke dalam kelompok;(2) merencanakan tugas;(3) membuat penyelidikan; (4) mempersiapkan tugas akhir; (5) mempresentasikan tugas akhir; (6) evaluasi, (Slavin,2010:20).

Pembelajaran GI salah satu model kooperatif yang dapat diterapakan pada mata pelajaran IPS materi perkembanagan teknologi. Secara langsung siswa menginvestigasi dan mencari informasi dengan mengetahui/menggunakan alat-alat produksi, komunikasi dan transportasi yang ada dilingkunganh sekitar. Adapun rumusan masalah pada penelitian ini; (1) Bagaimanakah hasil proses pembelajaran IPS siswa yang diajarkan dengan model pembelajaran kooperatif tipe Grup Investigasi dan tipe STAD mata pelajaran IPS materi Perkembangan Teknologi yang diterapkan pada siswa sekolah dasar ?;(2) Bagaimanakah hasil analisis deskriptif model pembalajaran kooperatif tipe Grup Investigasi dan tipe STAD mata pelajaran IPS materi perkembangan teknologi yang diterapakan 
pada sekolah SSN dan RSSN ?; (3) Bagaimana keefektifan model pembelajaran kooperatif tipe Grup Investigasi dibandingkan tipe STAD mata pelajaran IPS materi perkembangan teknologi yang diterapkan pada siswa sekolah SSN dan RSSN?. Bertujuan untuk; (1) mengkaji hasil proses pembelajaran IPS siswa yang diajarkan dengan model pembelajaran kooperatif tipe Grup Investigasi dan tipe STAD mata pelajaran IPS materi Perkembangan Teknologi yang diterapkan pada siswa sekolah dasar; (2) mengkaji hasil analisis deskriptif model pembelajaran kooperatif Grup Investigasi dan model pembelajaran STAD mata pelajaran IPS materi perkembangan teknologi yang diterapakan pada sekolah SSN dan RSSN; dan (3) mengkaji keefektifan model pembelajaran kooperatif tipe Grup Investigasi dibandingkan dengan tipe STAD mata pelajaran IPS materi perkembangan peknologi yang diterapkan pada siswa sekolah SSN dan RSSN.

METODE PENELITIAN

Pendekatan yang digunakan dalam penelitian ini adalah kuantitatif dengan metode eksperimen dan memberikan unsur diskriptif untuk mengetahui gambaran selama proses pembelajaran. Sugiono (2010:107) Penelitian ini menggunakan cara Randomized Control Group Design, dimana responden benar-benar dipilih secara random dan diberi perlakuan serta ada kelompok pengontrolnya. Penelitian eksperimen ini menggunakan desain faktorial (2x2) dengan faktor utama model pembelajaran kooperatif (A) dengan ukuran $\mathrm{A}=1$ adalah model pembelajaran kooperatif tipe Group Investigasi dan $A=2$ adalah model pembelajaran kooperatif tipe STAD serta jenis sekolah (B) dengan ukuran $\mathrm{B}=1$ adalah sekolah SSN dan $B=2$ adalah sekolah RSSN. Sebagaimana dijelaskan pada desain berikut.

Desain Perlakuan Antara Faktor A dan B

\begin{tabular}{ccc}
\hline \multirow{2}{*}{ Faktor B } & \multicolumn{2}{c}{ Faktor $\mathrm{A}$} \\
\cline { 2 - 3 } & $\mathrm{A}=1$ & $\mathrm{~A}=2$ \\
\hline $\mathrm{B}=1$ & $\mathrm{Y}_{11}$ & $\mathrm{Y}_{12}$ \\
\hline $\mathrm{B}=2$ & $\mathrm{Y}_{21}$ & $\mathrm{Y}_{22}$ \\
\hline
\end{tabular}

(Sumber. Sugiono:2010)

Populasi penelitian ini adalah pencapaian kompetensi siswa kelas IV sekolah dasar (SD) Kota Parepare. Jumlah keseluruhan SD Negeri di Kota Parepare sebanyak 91 yang terbagi 2 jenis sekolah yaitu Sekolah Regular (RSSN) dan Sekolah Standar Nasional (SSN), dapat dilihat pada Tabel.

Populasi Sekolah Dasar Kota Parepare

\begin{tabular}{l|c|c}
\hline Jenis Sekolah & $\begin{array}{c}\text { Jumlah } \\
\text { Sekolah }\end{array}$ & Jumlah siswa \\
\hline $\begin{array}{l}\text { Sekolah Standar } \\
\text { Nasional (SSN) }\end{array}$ & 23 & $\begin{array}{c}\text { 24-35 siswa } \\
\text { per rombel }\end{array}$ \\
\hline $\begin{array}{l}\text { Sekolah } \\
\text { Mandiri/ }\end{array}$ & 67 & $\begin{array}{l}10-30 \text { Siswa } \\
\text { per rombel }\end{array}$ \\
$\begin{array}{l}\text { Reguler } \\
\text { (RSSN) }\end{array}$ & & \\
\hline \multicolumn{3}{l}{ (Sumber Depdiknas Kota Parepare) }
\end{tabular}

(Sumber. Depdiknas Kota Parepare)

Pengambilan sampel menggunakan teknik Purposive random sampling yakni teknik penarikan sampel yang dilakukan untuk tujuan tertentu saja dengan melihat karakteristik jenis sekolah. Terdapat dua jenis sekolah di Kota parepare, UUSPN Tahun 2003 Pasal 35 yang menyatakan bahwa Sekolah potensial/regular (RSSN), yaitu sekolah yang masih relatif banyak kekurangan/kelemahan untuk memenuhi kriteria sekolah yang sesuai dengan Standar Nasional Pendidikan. SSN, sekolah/madrasah yang telah atau hampir memenuhi Standar Nasional ke dalam kategori mandiri. Penelitian ini menggunakan 2 kelas eksperimen dan 2 kelas kontrol diambil dari 91 SD sebagai sampel yang ada di Kota Parepare, dan ada empat SD yang memiliki kondisi lingkungan yang sama. Teknik dan alat pengumpulan data menggunakan, dokumentasi,observasi, angket,dan tes. Analisis data berupa; (1) secara deskriptif dilakukan untuk menggambarkan atau memberikan informasi keadaan data kognitif siswa, data afektif belajar siswa, data psikomotorik belajar siswa dan data respon siswa setelah pembelajaran dalam bentuk ratarata, standar deviasi, varians dan diagram batan; (2) Uji keektifan model pembelajaran kooperatif tipe Group Investigasi. Kelas dikatakan tuntas belajar apabila kelas tersebut telah terdapat $75 \%$ peserta didik yang telah mencapai tuntas belajar dengan kriteria ketuntasan minimal (KKM) yang dicapai setipa siswa adalah 68. Berikut digunakan analisis inferensial ( uji normalitas, uji homogenitas dan uji perbedaan t-test. 


\section{HASIL DAN PEMBAHASAN}

\section{Pembelajaran Model GI dan STAD}

Hasil belajar siswa dipengaruhi banyak faktor. Secara umum faktor tersebut terbagi atas dua bagian, yaitu faktor dari dalam diri siswa seperti inteligensia, motivasi, minat, sikap, dan konsentrasi, dan faktor dari luar diri siswa, seperti lingkungan keluarga, lingkungan sekolah, dan lingkungan masyarakat. Pada faktor lingkungan sekolah ini dapat terbagi menjadi siswa, guru, kepala sekolah, perangkat pembelajaran meliputi media, bahan ajar dan penentuan model pembelajaran.

Penelitian ini menfokuskan pada penerapan model kooperatif yang didukung oleh beberapa perangkat pembelajaran. Proses pembelajaran, mencapai tujuan pembelajaran tersebut jika mendapat bimbingan yang bermakna dari guru sebagai pelaksana pembelajaran di kelas. Jadi, guru merupakan salah satu faktor yang menentukan tercapainya tujuan pembelajaran. Jika guru dapat melaksanakan tugasnya secara profesional, sejak merencanakan, memilih model pembelajaran, melaksanakan, mengevaluasi, dan menindaklanjuti hasil evaluasi, maka pencapaian tujuan pembelajaran tersebut dapat terukur. Sebaliknya, jika semua proses tersebut hanya berjalan apa adanya sesuai berjalannya waktu, maka tujuan pembelajaran tidak akan dapat dicapai secara baik.

Siswa diarahkan untuk senantiasa aktif baik dalam mengikuti penjelasan guru mengajukan pertanyaan atau ide/gagasan terhadap suatu permasalahan, menjawab pertanyaan, menyelesaikan tugas/latihan, berbagi ide dengan siswa lainnya, maupun dalam bekerjasama dengan siswa lain di kelas untuk memecahkan suatu masalah yang diberikan guru. Sejalan dengan pendapat Slavin (2010:220) bahwa penerapan pembelajaran kooperatif dengan model GI memiliki beberapa tahapan diantaranya;(1) mengidentifikasi topik dan membagi siswa ke dalam kelompok; (2)merencanakan tugas; (3)membuat penyelidikan;(4)mempersiapkan tugas akhir;(5) mempresentasikan tugas akhir; dan (6) evaluasi.. Aktivitas ini dapat dilakukan secara mandiri dan akan lebih baik jika dilakukan secara berkelompok atau kooperatif.

Model pembelajaran kooperatif yang efektif diajarakan adalah model GI baik di sekolah SSN maupun RSSN. Siswa terlibat mulai dari merencanakan topik dan bahan ajar. Keterampilan menyediakan media yang digunakan dalam pembelajaran sampai pada keterlibatan siswa secara kelompok dalam mereduksi dan menganalisis topik. Artinya, melalui pembelajaran kooperatif GI siswa dapat memaksimalkan kegiatan secara efektif untuk mencapai tujuan belajar. Penjelasan ini dipertegas oleh pendapat Trianto (2012:59) bahwa pembelajaran kooperatif GI mendorong siswa untuk lebih kreatif dan kritis dan mengajari siswa untuk lebih terarah dan terlibat langsung dalam menentukan topik yang disenangi untuk diinvestigasi.

Hasil penelitian ini menunjukkan bahwa melalui pembelajaran kooperatif dengan model GI pada mata pelajaran IPS materi perkembangan teknologi. Pelaksanaan pembelajaran di sekolah SSN dan RSSN, Siswa berinteraksi sesama kelompok dalam bentuk diskusi yang pada akhirnya menghasilkan suatu kesimpulan. Siswa melakukan investigasi terhadap suatu topik secara sistematis dan analitik. Hal ini mempunyai implikasi yang positif terhadap pengembangan keterampilan penemuan dan membentu mencapai tujuan. Pemahaman secara mendalam terhadap suatu topik yang dilakukan melaui investigasi. Model GI melatih kemampuan akademik siswa sehingga tujuan pembelajaran tercapai. Keberhasil siswa dalam proses pembelajaran sependapat dengan Mary (2007) menyatakan bahwa pembelajaran kooperatif memiliki manfaat akademis, sosial, dan psikologis, prestasi akademis yang lebih tinggi yang berhubungan dengan hasil belajar, pembelajaran kooperatif. Memberikan keuntungan yang baik bagi siswa pada setiap kelompok yang bekerjasama menyelesaikan tugas-tugas akademik. Pendapat ahli di atas tampak pada hasil penelitian ini.

Hasil proses pembelajaran menunjukkan secara diskriptif kognitif belajar siswa, ada perbedaan rata-rata pembelajaran IPS siswa dari keempat kelas. Sebelum penelitian ratarata kognitif belajar siswa dari keempat kelas tidak jauh berbeda. Namun, setelah penelitian siswa kelas GI baik pada SSN maupun RSSN memperoleh rata-rata kognitif belajar IPS yang lebih tinggi dibandingkan dengan kognitif belajar IPS siswa di kelas STAD baik pada SSN muapun RSSN. Hasil pembelajaran yang diperoleh siswa tidak hanya pada aspek kognitif yang ditunjukkan oleh meningkatnya hasil belajar siswa, tetapi juga pada aspek afektif dan psikomotorik.

Afektif belajar siswa pada kelas GI SSN danj RSSN yang paling menonjol keaktifan dalam melaksanakan prosedur kerja diskusi. Pelaksanaan pembelajaran siswa berani untuk 
memimpin dan dipimpin dalam keguatan diskusi. Mulai dari awal pembelajaran hingga akhir pembelajaran siswa Mengikuti dan membuat catatan penting. Sedangkan kelas STAD SSN dan RSSN. Siswa mengikuti jalannya pembelajaran dan lebih menonjol pada keaktifan siswa dalam menganalisis sumber/informasi untuk memecahkan masalah. Selama proses pembelajaran terlihat sikap saling menghormati dan menghargai pendapat atau ide siswa lain serta munculnya tanggung jawab dalam melaksanakan tugas kelompok. Tanggung jawab ini dapat dilihat dari aktivitas siswa yang semakin meningkat dalam melibatkan diri pada setiap kegiatan kelompok di kelas selama proses pembelajaran. Aktivitas tersebut dapat dilihat dari aktivitas diskusi kelompok, diskusi kelas, menyiapkan laporan hasil kerja, mempresentasikan hasil kerja, dan tetap berada di kelompok selama diskusi kelompok serta mengajukan pertanyaan kepada guru ketika ada permasalahan di kelompok yang belum dapat diselesaikan.

Aktivitas siswa selama proses pembelajaran ini sangat menunjang siswa untuk menguasai materi yang diberikan guru sehingga hasil belajar IPS siswa semakin meningkat. Dilihat dari aspek psikomotorik belajar siswa kelas GI SSN dan RSSN paling menonjol adalah terampil dalam mengungkapkan saran. Siswa lebih terampil dalam memilih sumber/informasi pembelajaran yang tepat sehingga siswa lebih kreatif dalam memunculkan ide alternatif pada kegiatan diskusi kelompok. Berbeda dengan kelas STAD SSN dan RSSN lebih menonjol keterampilan dalam memilih sumber/informasi, dan Terampil dalam mempersiapkan media untuk presentasi hasil kerja.

Peningkatan hasil belajar siswa selama proses pembelajaran dimungkinkan karena pembelajaran dengan model GI yang diajarkan melalui mata pelajaran IPS materi perkembangan teknologi. Siswa dapat mengetahui secara utuh model GI dan kaitannya dengan perkembangan teknologi. Pengetahuan ini mendorong siswa untuk lebih aktif dalam mengajukan pertanyaan dan berdiskusi terhadap materi yang diberikan guru. Pernyataan tersebut sejalan dengan pendapat Trianto (2012:78) yaitu melalui pembelajaran GI melatih keterampilan komunikasi, masyarakat belajar dan proses kelompok yang baik siswa. Sehingga dapat diperoleh pemahaman yang lebih mendalam tentang pengetahuan yang dimilikinya. Karakteristik yang dimiliki oleh model pembelajaran GI inilah yang kemudian menjadi penentu meningkatnya hasil belajar IPS siswa jika dibandingkan dengan hasil belajar IPS siswa selama ini yang hanya menggunakan model pembelajaran kooperatif STAD.

Keberhasilan siswa dalam memperoleh hasil belajar yang diharapkan dimungkinkan terjadi. Pembelajaran dengan model kooperatif GI merupakan strategi belajar kooperatif yeng menempatkan siswa ke dalam kelompok untuk melakukan investigasi terhadap suatu topik. Fokus utama untuk melakukan investigasi terhadap suatu topik atau objek khusus materi perkembangan teknologi. Mencari dan mengumpulkan informasi dilingkunga sekitar salah satunya di perpustakaan, internet, media massa dan elektronik sesuai topik yang dipilih.

Model pembelajaran GI akan sangat berdampak positif terhadap hasil belaja siswa materi perkembangan teknologi di sekolah SSN dan RSSN. Siswa diberi kebebasan memilih topik, siswa juga terlatih untuk mencari dan mengumpulkan sumber informasi baik di dalam dan di luar lingkungan sekolah, yang tentunya melalui pengawasan dari guru. Motivasi inilah yang menimbulkan dampak positif terhadap hasil belajar siswa. Sehingga, siswa dibekali keterampilan hidup (life skill) yang berharga dalam kehidupan bermasyarakat. Penjelasan ini sependapat dengan Anggraini (2010) Guru menerapkan model pembelajaran GI dapat mencapai tiga hal, yaitu memotivasi siswa unutk lebih mandiri, dapat belajar dengan penemuan, belajar isi dan belajar untuk bekerjas secara kooperatif. Pembelajaran yang dilakukan pada kelas yang diajar dengan model pembelajaran kooperatif tipe STAD di sekolah SSN dan RSSN. Siswa kurang termemotivasi untuk meningkatkan aktivitas belajar. Keadaan ini terjadi, karena siswa terkesan hanya terfokus pada satu konsep saja yang diberikan oleh guru. Siswa tidak diberi kesempatan untuk memilih topik yang disenangi. Model pembelajaran ini kurang memberi kebebasan kepada siswa untuk lebih kreatif secara mandiri. siswa terlihat kurang aktif dalam bekerjasama dengan anggota kelompok. Pembelajaran didominasi siswa yang pandai dalam melaksanakan langkah-langkah STAD.

Disimpulkan pula pada angket siswa setelah proses pembelajaran, menunjukkan bahwa ada perbedaan respons siswa dari keempat kelas. Respons siswa pada kelas model pembelajaran kooperatif tipe GI lebih tinggi dari pada kelas model pembelajaran kooperatif tipe STAD baik diterapkan pada jenis sekolah SSN maupun RSSN. Tampak 
bahwa respons siswa setelah mendapat pembelajaran baik GI dan STAD baik diterapkan pada jenis sekolah SSSN maupun RSSN mengalami perbedaan. Jika ditinjau dari model pembelajaran, maka kelas yang diajar dengan model pembelajaran kooperatif tipe GI lebih baik dari pada kelas yang diajar dengan model pembelajaran kooperatif tipe STAD. Begitu juga, jika ditinjau dari jenis sekolah, maka jenis sekolah SSN lebih baik dari pada jenis sekolah RSSN.

Model pembelajaran GI mendapat respons yang sangat baik dari siswa karena dalam pelaksanaannya, model ini mampu mengaktifkan siswa di kelas. Aktivitas siswa tersebut terjadi karena guru dapat melaksanakan model ini dengan baik. Berbagai pernyataan yang digunakan dalam mengkaji responss siswa tampak bahwa pada kedua model pembelajaran kooperatif ini, siswa terlibat secara maksimal dalam proses pembelajaran utamanya ketika berdiskusi di kelompok atau di kelas, bertanya, dan menjawab pertanyaan serta mendapat kesempatan untuk berpikir sehingga mampu mengambil manfaat dari materi dan proses pembelajaran yang diikuti. Peningkatan aktivitas belajar siswa merupakan wujud ketertarikan siswa dalam mengikuti pembelajaran dengan model pembelajaran kooperatif GI.

Proses pembelajaran model GI begitu menarik sehingga berbagai aktivitas dan tugastugas yang diberikan guru dapat diikuti oleh siswa dengan antusiasme tinggi. Aktivitas siswa tersebut menjadi bertambah baik ketika guru menyajikan materi pelajaran dengan memanfaatkan masalah kontekstual, materi pelajaran dikaitkan dengan kegiatan sehari-hari siswa. Sedangkan, model pembelajaran STAD ketertarikan siswa masih kurang dilihat dari hasil respos siswa setelah pembelajaran. Sehingga, perhatian dan kerjasama kelompok siswa selama proses pembelajaran pada model GI SSN dan RSSN masih lebih baik dibandingkan dengan model STAD.

Selama proses pembelajaran ada beberapa hal yang menghambat jalannya kegitan pembelajaran. Keterbatasan waktu dan kreatifitas guru dalam membuat serta menggunakan media pembelajaran masih kurang. Kurangnya pengawasan guru terhadap aktivitas siswa dalam kegiatan investigasi. Siswa bekerja secara kelompok dari tahap perencanaan sampai investigasi untuk menemukan hasil jadi metode ini sangat komplek, sehingga guru harus mendampingi siswa secara penuh agar mendapatkan hasil yang diinginkan. Hal ini diakibatkan jumlah siswa dalam satu kelas sangat padat.

\section{Kefektifan Model Pembelajaran GI}

Uji kefektifan belajar siswa dilihat dari tiga aspek yaitu, ketutasan belajar secara klasikal, uji perbedaan dan peningkatan hasil belajar siswa. Ketuntasan belajar siswa dilihat secara klasikal menunjukkan pada kelas GI yang diterapkan pada sekolah SSN lebih tinggi dibandingkan kelas STAD yang diterapkan pada sekolah SSN. Hasil ketuntasan belajar kelas GI yang diterapkan pada sekolah RSSN secara klasikal lebih tinggi dibandingkan dengan kelas STAD yang diterapkan pada sekolah RSSN. Karena besarnya ketuntasan belajar klasikal yang harus dicapai adalah $75 \%$ dari nilai KKM individu siswa yakni 70, maka secara klasikal kelas GI diterapkan pada sekolah SSN dan RSSN saja yang memenuhi dari ketetapan yang telah ditentukan.

Berdasarkan perbedaan Anava dua jalan digunakan untuk menguji hipotesis perbedaan perlakuan antara faktor A dan faktor B beserta interaksinya $(\mathrm{AB})$. Faktor $\mathrm{A}$ adalah model pembelajaran kooperatif, faktor $\mathrm{B}$ adalah jenis sekolah dan $\mathrm{AB}$ adalah interaksi antara model pembelajaran kooperatif dengan jenis sekolah. Diperoleh kesimpulan baik Faktor A maupun faktor B "terdapat pengaruh yang signifikan antara model pembelajaran kooperatif terhadap hasil belajar IPS siswa sekolah dasar" dan terdapat pula signifikan antara jenis sekolah terhadap hasil belajar IPS siswa sekolah dasar". Begitu pula faktor $\mathrm{AB}$ signifikan diperoleh kesimpulan "terdapat interaksi antara model pembelajaran kooperatif dan jenis sekolah terhadap hasil belajar IPS siswa sekolah dasar". Hasil uji faktor $\mathrm{AB}$ nilainya signifikan maka akan diteruskan pada uji lanjut perbedaan satusatu untuk melihat perbedaan rata-rata kognitif belajar siswa dari masing-masing keempat perlakuan.

Setelah uji perbedaan Anava dua jalur selanjutnya dilakukan uji lanjut. Diperoleh hasil: (1) pengujian hipotesis satu-satu menunjukkan pembelajaran IPS siswa yang diajar menggunakan model pembelajaran tipe GI lebih baik dari pada hasil belajar IPS siswa yang diajar dengan model pembelajaran kooperatif tipe STAD; (2) hasil belajar belajar IPS siswa pada jenis sekolah SSN lebih baik dari pada hasil belajar IPS siswa pada jenis sekolah RSSN; (3) hasil belajar belajar IPS siswa yang diajar menggunakan model pembelajaran tipe GI lebih baik dari pada hasil 
belajar IPS siswa yang diajar dengan model pembelajaran kooperatif tipe STAD khusus pada jenis sekolah SSN; (4) hasil belajar IPS siswa yang diajar menggunakan Model Pembelajaran tipe GI pada sekolah SSN dengan hasil belajar IPS siswa yang diajar dengan model pembelajaran kooperatif tipe GI pada sekolah RSSN; (5) hasil belajar IPS siswa yang diajar menggunakan Model Pembelajaran tipe GI pada sekolah SSN lebih baik dari pada hasil belajar IPS siswa yang diajar dengan model pembelajaran kooperatif tipe STAD pada sekolah RSSN; (6) hasil belajar IPS siswa yang diajar menggunakan Model Pembelajaran tipe GI lebih baik dari pada hasil belajar IPS siswa yang diajar dengan model pembelajaran kooperatif tipe STAD khusus pada jenis sekolah RSSN; dan (7) hasil belajar IPS siswa yang diajar menggunakan model pembelajaran tipe STAD sekolah SSN lebih baik dari pada hasil belajar IPS siswa yang diajar dengan model pembelajaran kooperatif tipe STAD sekolah RSSN. Dilihat dari karakteristik model pembelajaran GI dan STAD yang digunakan dalam penelitian ini, tampak bahwa perbedaan hasil belajar siswa tersebut memang tampak terjadi.

Hasil analisis data menunjukkan bahwa ada perbedaan hasil belajar setelah siswa mengikuti pembelajaran dengan model-model tersebut. Secara totalitas, hasil pengujian uji-t secara terpisah diatas mengindentifikasikan bahwa model pembelajaran kooperatif GI lebih baik dari model pembelajaran tipe STAD dengan memperhatikan keberadaan dan posisi jenis sekolah yaitu sekolah SSN dan RSSN. Perbedaan itu dapat dilihat dari perkembangan belajar siswa dari segi kognitif, afektif dan psikomotorik. Disebabkan oleh siswa tidak tertarik terhadap model pembelajaran yang diajarkan secara berulang-ulang pada materi perkembangan teknologi. Serta, penentuan subtopik yang didiskusikan sesuai keinginnya. Persentase kemampuan kognitif, afektif dan psikomotorik siswa pada sekolah SSN dan RSSN setelah diberi perlakuan mengindifikasikan bahwa persentase kemampuan kognitif siswa pada kelas yang diajar model pembelajaran kooperatif GI lebih baik dari pada kelas yang diajar dengan model pembelajaran kooperatif tipe STAD.

Peningkatan kognitif belajar siswa dapat dilihat dengan menggunakan analisis data gain. Kategori nilai peningkatan kognitif belajar adalah $\mathrm{g}<0,3=$ rendah, $0,3 \leq \mathrm{g}<0,7=$ sedang, $\mathrm{g} \geq 0,7=$ tinggi. Hasil analisis besarnya nilai peningkatan kognitif belajar keempat kelas menunjukkan bahwa peningkatan kelas nilai gain keempat kelompok berada pada $0,3 \leq \mathrm{g}<$ 0,7 , maka peningkatan kognitif belajar keempat kelas berkategori sedang. Akan tetapi nilai peningkatan kognitif belajar yang tertinggi berada pada kelas GI SSN dan kelas GI RSSN. Hal ini menunjukkan bahwa model pembelajaran kooperatif GI mata pelajaran IPS materi perkembangan teknologi lebih baik baik di sekolah SSN maupun RSSN. Perbedaan karakteristik sekolah sangat mempengaruhi hasil belajar siswa. Beberapa hal yang mempengaruhi keberadaan jenis sekolah yaitu, sarana prasaran yang dimiliki oleh sekolah SSN lebih baik dibandingkan sekolah RSSN.

\section{KESIMPULAN}

Dari hasil pembahasan dapat disimpulkan bahwa, Hasil analisis data deskriptif menunjukkan bahwa ada perbedaan hasil belajar setelah siswa mengikuti pembelajaran dengan model-model tersebut. Secara terpisa mengindentifikasikan bahwa model pembelajaran kooperatif GI lebih baik dari model pembelajaran tipe STAD. Model pembelajaran kooperatif tipe GI pada sekolah SSN dan RSSN lebih efektif dari pada model pembelajaran kooperatif tipe STAD. Model pembelajaran kooperatif GI lebih baik diterapkan di sekolah SSN dibandingkan sekolah RSSN.

\section{DAFTAR PUSTAKA}

Ahamdi Lif Khoiru dan Sofan Amri. 2011. Mengembangkan Pembelajaran IPS Terpadu. Jakarta: Prestasi Pustakarya.

Anggraini Lela. 2010. "Penerapan Model Pembelajaran Investigasi Kelompok untuk Meningkatkan Kemampuan Pemecahan Masalah Matematika Siswa Kelas Viii-4 Smp Negeri 27 Palembang." Jurnal Pendidikan Matematika, Volume 4.No.1. Hal. 21.

Deena Goran dan Braude. 2007. "Social and Cooperative Learning in the Solving of Case." Jurnal Educational Volume 69 No 5. Hal.123.

Departemen Pendidikan Nasional. 2008. Panduan Penyelenggaraan Sekolah Standar Nasional (SSN Dan Sekolah Bertaraf Internasional (SBI). Jakarta: Putra Baktimandiri

Gunawan Rudy. 2011. Pendidikan IPS filosofis, Konsep dan Aplikasi. Bandung: Alfabeta.

Jauhar Mohammad. 2011. Implementasi PAIKEM dari Behavioristik sampai 
Konstruktivistik. Jakarta: Prestasi Pustakarya.

Lenore dan Henderson. 2006. Cooperative Learning Through Collaborative Faculty-Student Research Teams. Journal Sociology, Education.Volume 55 No. 11. Hal. 252-262.

Mary dan Leman. 2007. "Influence of Learning Style Heterogeneity on Cooperative Learning." NACTA Journal of Education, Volume 51 No. 6. Hal. 1722.

Rusman.2010. Model-Model Pembelajaran. Jakarta: PT. Raja Grafindo Persada.

Slavin Robert. 2010. Cooperative Learning. Bandung: Nusa media.

Sugiyono. 2010. Metode Penelitian Pendidikan. Bandung: Alfabeta.

Trianto. 2012. Mendesain Model Pembelajaran Inovatif dan Progresif. Jakarta: PT Bumi Aksara

Udin S. Winataputra. 2009. Materi. Materi dan Pembelajaran IPS SD. Jakarta: Universitas Terbuka.

Uno B Hamsah dan Satria koni. 2012. Assessment Pembelajaran. Jakarta: PT Bumi Aksara.

Walker dan Alexis. J. 1996. "Cooperative Learning In The College Classroom." Journal subject Sociology, Education. United States: National Council on Family Relations. Volume 45 No 9. Hal. 327.

Warsono dan Hariyanto. 2012. Pembelajaran Aktif Teori dan Assesmen. Bandung: PT Remaja Rosdakarya 